\title{
Türkiye’de Yoksullukla Mücadele Politikalarının Uzmanların Gözüyle Değerlendirilmesi*
}

\section{Evaluation of Social Policies For Poverty Alleviation in Turkey According to Experts Opinions}

\author{
Dr. Öğr. Üyesi Dilek ÖZSOY (D) 1 , Prof. Dr. Kasım KARATAŞ (D) 2
}

\begin{abstract}
$\ddot{\mathbf{O} z}$
Bu makalede, Türkiye'deki yoksullukla mücadeleye yönelik sosyal politikaların tanımı, amacı, hedefi ve temel alınan yaklaşımlar uzman görüşleri doğrultusunda irdelenmektedir. Bu kapsamda yoksullukla mücadeleye ilişkin sosyal politika belirleme ve uygulama aşamalarında görev alan bürokrat, akademisyen, siyasetçi ve politika uygulayıcıların bakış açısına göre değerlendirmeler yer almaktadır. Makalede “Türkiye'de Yoksullukla İlgili Sosyal Politikalar: Bir Değerlendirme Çalışması” başlıklı doktora tezinde yer alan ilk bölüme ait nitel araştırma sonuçlarına yer verilmiştir. Bu doğrultuda uzman gözüyle Türkiye'de var olan yoksullukla mücadele politikalarının nasıl bir anlam ifade ettiği, hangi amaç ve hedeflerin temel alındığı ve yoksullukla mücadele politikalarının temelindeki yaklaşımlara ilişkin değerlendirme sonuçları aktarılmıştır. Araştırmada yoksullukla mücadeleye yönelik sosyal politikaların ağırlıklı sosyal yardımlara dayandığı, bu alanda yapılacak mücadelede kaliteli eğitim, kaliteli sağlık haklarına ulaşmanın önemli olduğu, yoksulluğun nesiller arası aktarımının önleneceği politikaların temel alınması gerekliliği vurgulanmıştır.
\end{abstract}

Anahtar Kelimeler: Yoksulluk, sosyal politika, sosyal yardım, sosyal hizmet

Makale Türü: Araştırma

\begin{abstract}
In this article, the definition of social policies for poverty alleviation in Turkey, aims, objectives and underlying approach are examined in accordance with expert opinion. In this context, there are evaluations from the perspective of bureaucrats, academicians, politicians and policy practitioners who take part in social policy determination and implementation stages related to poverty alleviation. In the article "Social Policies Related to Poverty in Turkey: An Evaluation Study" located in the doctoral thesis of the first part of qualitative research results are included. In this regard, experts have eyes with which to fight poverty in Turkey expressed a sense of how the policies, which aim and objectives and results of the evaluation, which is based on the fundamental approach to poverty alleviation policies were transferred. In this research, high reliance of the social policies addressing poverty alleviation on aids, the importance of the quality education and access to right to health for poverty alleviation and the need for the policies aiming at preventing poverty transmission between generations have been underlined.
\end{abstract}

Keywords: Poverty, social policy, social assistance, social service

Paper Type: Research

\footnotetext{
*Bu çalışma, ilk yazarın "Türkiye'de Yoksullukla İlgili Sosyal Politikalar: Bir Değerlendirme Çalışması” başlıklı doktora tezinin bir bölümünden üretilmiştir.

${ }^{1}$ Nişantaşı Üniversitesi, IİSBF, dilek.ozsoy@nisantasi.edu.tr.

${ }^{2}$ Hacettepe Üniversitesi, İ̈BF, kkaratas@ hacettepe.edu.tr.

Atıf için (to cite): Özsoy, D. ve Karataş, K. (2020). Türkiye'de yoksullukla mücadele politikalarının uzmanların gözüyle değerlendirilmesi. Afyon Kocatepe Üniversitesi Sosyal Bilimler Dergisi, 22(4), 989-1004.
} 


\section{Giriş}

Thorbecke (2006) yoksulluğun "öncelikle beslenme, barınma, sağlık, eğitim, kamu mallarına erişim konularında, ardından bilgiye erişim, karar alma mekanizmalarına katılım, demokrasi ve özgürlüğün derecesiyle tanımlanan yönetim biçiminin özellikleri gibi konulardaki iyileşmeleri içine alacak şekilde günden güne genişlediği” görüşünü savunmaktadır (Şenses, 2013, s. 686).

Yoksulluk, bünyesinde pek çok sosyal sorunu barındırması nedeniyle bu alandaki mücadelede etkinliğin sağlanması ve politikaların ayrıntılı düzeyde değerlendirilmesi önemlidir. Türkiye'deki yoksulluk oranlarında göreliliğin yüksek olması ve süreklilik arz etmesi nedeniyle yoksullukla mücadele, "ekonomik büyüme, istihdam ve işgücü politikaları" ile beraber sosyal devlet anlayışının ve yoksul yanlısı politikaların geliştirilmesini zorunlu kılmaktadır (Gül \& Sallan Gül, 2008, s. 363).

Yoksullukla mücadeleye yönelik sosyal politikaların bileșenleri dikkate alındığında sosyal yardımlar, sosyal hizmet, sosyal güvenlik, eğitim, sağlık, barınma konuları öne çıkmaktadır. Bu bileşenlerin yanında engelli, yaşlı, kadın, çocuk, aile ve göçmen politikaları da yoksullukla mücadele politikalarıyla ilişkilidir.

Türkiye'de yoksullukla mücadelede yoksul kesime sağlanan sosyal desteklerle beraber yoksul kesimler için aktarılan kaynak ve hizmet çeşitliliğinde artış olmuştur. Bu artışlar GSYH içinde sosyal politikalara ayrılan kaynak oranlarındaki artışlarda da görülmektedir. 2000'li yıllardan sonra yoksulluk oranlarındaki önemli ölçüde azalmaya karşın sosyal yardım yararlanıcısı hanelerin ve bireylerin sayısında yıllar itibariyle düşme olmaması, belirlenecek politikalarda önemsenmesi gereken bir unsur olarak görünmektedir.

Sosyal politikalar kapsamında yer alan yoksullukla mücadele politikalarının gerek kapsadığı hedef kitle gerekse bu alana ayrılan kaynak açısından büyüklüğü dikkate alındığında bu politikaların önemi açıkça görülmektedir. Bu yönüyle politikaların oluşturulması noktasında konuyla ilgili uzmanların değerlendirmeleri politikaların etkinliğinin artırılması noktasında önem kazanmaktadır.

\section{Yöntem}

\subsection{Araştırmanın Amacı}

$\mathrm{Bu}$ araştırmanın temel amacı, yoksullukla mücadele politikalarının belirlenmesi ve uygulanması hakkında görüş sahibi olan uzmanların gözünden, Türkiye'deki yoksullukla mücadele politikalarının değerlendirilmesidir. Bu doğrultuda üretilecek bilgi ile Türkiye' de var olan politika yapıcıları ve uygulamaları etkilemek hedeflenmiştir.

\subsection{Araştırmanın Yöntemi}

Bu araştırma kapsamında, birinci adımda Türkiye' de yoksullukla mücadele politikalarına ilişkin göstergeleri oluşturmak amacıyla belli başlı politika belgeleri incelenmiş ve çözümlenmiştir.

$\mathrm{Bu}$ araştırmada, nitel araştırma yöntemi kullanılmıştır. Araştırmada sosyal politika oluşumuna katkı sağlayan bürokrat, akademisyen, uygulayıcılar ve siyasi parti temsilcileriyle yarı yapılandırılmış görüşme formu kullanılarak derinlemesine görüşmeler gerçekleştirilmiştir.

\section{3. Çalışmanın Evreni ve Örneklemi}

Araştırmanın evreni, bu politikaların oluşumuna doğrudan veya dolaylı olarak katkı sağlayan uzmanlar (bürokrat, akademisyen, uygulayıcılar ve siyasi parti temsilcileri)'dır. Bu 
doğrultuda, Türkiye'de yoksullukla mücadeleye ilişkin genel bakış açısının yansıtılabilmesi ve politikaların içeriğinin değerlendirilebilmesi için katılımcılar ağırlıklı olarak sosyal politika alanında kamuda görev yapan uzman ve yöneticilerden seçilmiştir.

Görüşlerine başvurulan uzman kişiler amaçlı örnekleme yöntemiyle belirlenmiştir. Araştırmada çoklu bakış açısını yakalayabilmek için politika belirlemede ve uygulamada farklı rolü olan kurumlardan toplam 23 uzmanla görüşülerek, değerlendirmeleri temel alınmıştır. Görüşülenler bürokrat, akademisyen, siyasi temsilci ve uygulayıcılar şeklinde alt gruplara ayrılmıştır: Bu doğrultuda Cumhurbaşkanlığı Strateji ve Bütçe Başkanlığı uzmanları (3), Aile, Çalı̧̧ma ve Sosyal Hizmetler Bakanlığındaki uzman ve yöneticiler (10), sosyal politika alanında değerlendirmelerde bulunabilecek akademisyenler (4), bu politikalara ilişkin siyasi partilerin görüşlerini aktaran yetkililer (3) ve sosyal politika uygulayıcıları (3) arasından seçilen uzmanların deneyimleri temel alınarak, yoksullukla mücadele politikalarına ilişkin değerlendirmeleri derlenmiştir. Katılımcılar görüşme sırasına göre kodlanmış olup, doğrudan alıntılarda bu kodlama kullanılmıştır.

\subsection{Araştırma Etiği}

Araştırma için Hacettepe Üniversitesi Etik Komisyon izni (09 Ekim 2018 / 35853172300 ) alınmıştır. Araştırmada, değerlendirilmeye alınan görüşler birincil kişilere ait olup, görüşme yapılan uzmanların anlatılarından kesitler yer almaktadır. Kendi istemleri doğrultusunda, katılımcıların gerçek isimlerinin kullanılması uygun görülmemiş, alıntıların aktarımı, konuya ilişkin uzman görüşü şeklinde verilmiştir.

Görüşmenin başında, katılımcıların ses kayıtlarının alınacağı, kişilerin kimlik bilgisi ve yanıtlarının gizli kalacağı ve görüşülen kişiye olumsuz yansıyacak herhangi bir durumun söz konusu olmayacağı bilgisi verilmiştir.

\subsection{Veri Toplama Süreci}

Araştırmanın verileri 2018 yılının Ekim, Kasım, Aralık aylarında toplanmıştır. Yirmi üç uzman ile yapılan görüşmeler en az 30 en fazla 136 dakika sürmüş olup, ortalama görüşme süresi 105 dakikadır.

Görüşmeler, beş ana başlık altında toplam 30 sorudan oluşan görüşme formuna uyularak yürütülmüştür. Araştırmada yer alan ana başlıklar, yoksullukla mücadeleye ilişkin politikaların tanımlanması, politikaların yapısı, politikaların etkisi, politikaların yeterliliği ve etkinliği olarak belirlenmiştir.

Katılımcıların ağırlıklı olarak kamu kurumlarında görev almaları nedeniyle, görüşmeler, mesai saatlerinde ve kendi iş ortamlarında gerçekleştirilmiştir. Görüşme öncesi uzmanlara e-posta yoluyla görüşme formu gönderilmek suretiyle yapılacak görüşmeye ilişkin genel bir hazırlık yapmalarına olanak sağlanmıştır.

\subsection{Verilerin Çözümlenmesi}

Politika belgelerinin incelenmesi ve çözümlemesinden elde edilen veriler betimsel analiz kapsamında genel temalar doğrultusunda sınıflandırılmıştır. Sonraki aşamalarda aynı yöntem ile yoksullukla mücadele politikalarının hedef kitleler üzerindeki etkisi, politikaların yeterliliği ve etkinliğine yönelik katılımcıların görüşleri ortaya çıkarılmıştır.

Araştırmada, yoksullukla mücadele politikaların uzman gözüyle değerlendirilmesinde ağırlıklı olarak "yorumlayıcı yaklaşım" temel alınmıştır.

Çalışma kapsamında katılımcılara beş ana başlık altında 30 soru yöneltilerek, onlardan sosyal politikalar hakkında değerlendirme yapmaları istenmiştir. Ülkemizdeki yoksullukla ilgili sosyal politika çerçevesinin oluşturulmasında ve değerlendirilmesinde temel alınan başlıklar aşağıda sunulmuştur: 
1.Yoksullukla mücadeleye ilişkin politikaların tanımlanması
○
Politikanın tanımlanması
- Politikanın amacı ve hedefi

2.Yoksullukla mücadeleye ilişkin politikaların yapısı

o Politikanın hedef kitlesi

○ Politikanın temel bileşenleri

○ Politikanın niteliği

○ Politikadaki temel yaklaşımlar

3.Yoksullukla mücadeleye ilişkin politikaların etkisi

○ Politikaların engelliler üzerindeki etkisi

○ Politikaların yaşlılar üzerindeki etkisi

○ Politikaların kadınlar üzerindeki etkisi

○ Politikaların çocuklar üzerindeki etkisi

○ Politikaların aileler üzerindeki etkisi

○ Politikaların göçmenler üzerindeki etkisi

4.Yoksullukla mücadeleye ilişkin politikaların yeterliliği
$\circ \quad$ Yasal yeterliliği
○ Yönetsel yeterliliği
○ Finansal yeterliliği
○ Uzmanlaşmış İnsan gücü yeterliliği
○ Veri yeterliliği

5.Yoksullukla mücadeleye ilişkin politikaların etkinliği

○ Politika uygulamalarının eksik yönleri

○ Politika uygulamalarının hatalı yönleri

Çözümleme, görüşmelerin yer aldığı ses kayıtlarının raporlanması yoluyla gerçekleştirilmiştir. Görüşmelerin deşifresinin tamamlanması sonrasında veriler kategorize edilmiştir. Kategorilerin hazırlanmasında yarı yapılandırılmış görüşme formunun alt başlıklarına dayanılarak yorumlayıcı bir çalışma yürütülmüştür. Bu doğrultuda başlıklara uygun kategoriler oluşturularak, veri olarak kullanılacak görüşler yorumlanmıştır.

\section{Bulgular}

Yoksullukla mücadele politikalarının tanımlanması, politikaların temelinde yer alan amaç ve hedefler ile bu politikaların temelindeki yaklaşımların değerlendirilmesi amacıyla katılımcılara üç soru yöneltilmiştir:

"Yoksullukla ilgili sosyal politika dendiğinde ilk aklınıza gelen nedir?"

"Yoksullukla ilgili sosyal politikaların amacı, hedefi hakkında ne düşünüyorsunuz?"

"Yoksullukla mücadele politikalarının temelinde yer alan yaklaşımlar hakkındaki düşünceleriniz nedir?" 
İlk soruya ilişkin görüşler, yoksullukla mücadele politikalarının tanımlanması, ikinci soruya ilişkin görüşler bu politikaların amacı ve hedefi, üçüncü soruya ilişkin görüşler politikalarda temel alınan yaklaşım kapsamında değerlendirilmiştir.

\subsection{Yoksullukla Mücadele Politikalarının Tanımlanması}

Araştırmada, yoksullukla mücadeleye yönelik sosyal politikaların değerlendirmesinde, katılımcıların bu kavrama nasıl bir anlam yükledikleri ortaya çıkarılmıştır.

Katılımcıların büyük çoğunluğu, yoksullukla ilgili sosyal politikaların teorik ve pratik olarak farklı anlamları ifade ettiğini belirtmişlerdir. Araştırmaya katılan katılımcılar, var olan yapıdaki yoksullukla ilgili sosyal politikaların ağırlıklı olarak sosyal yardımlar üzerinden yürütüldüğünü vurgulamakla beraber ideal olanın sosyal yardım, sosyal hizmetler ve sosyal güvenlik olmak üzere üçlü bir yapı ekseninde olması gerektiğidir. Bu doğrultuda, katılımcıların büyük bir bölümü, yoksullukla ilgili sosyal politikalar dendiğinde ilk akla gelen kavramı sosyal yardım olarak belirtmişlerdir. Sosyal yardımları sosyal hizmetler izlemiştir. Sosyal yardımlar ve sosyal hizmetleri takip eden üçüncü araç yoksullukla mücadele konusunda ekonomik alanda kayıt dışılığın ortadan kaldırılmasıyla oluşturulacak sağlam bir sosyal güvenlik sistemidir.

Yoksullukla mücadele kapsamında, sosyal politika alanında ilk akla gelen kavramın sosyal yardım olduğunu belirten katılımcılar, gerek uygulama aşamalarında gerekse toplumsal algı yönüyle özellikle ayni sosyal yardımların temel alındığını belirtmişlerdir. Buna ilişkin katılımcı değerlendirmeleri şu şekildedir:

"Maalesef sadece yardım geliyor. Bizde yoksulluk deyince yardim odakl, verme odaklı bir bakış açımız var" (3)

"Sosyal politika deyince toplumda da öyle bizim de aklımızda en yaygın kömür dağıtmak, gıda dağıtmak, vakıftan para vermek. Üçü öne çıklyor yani sosyal yardım öne çıkıyor. Oysa sosyal politika sadece sosyal yardımdan ibaret değil şimdi sosyal politika deyince bu yoksulluğun oluşmasında ĕgitim durumunuzun katkısı var, ülkenizin ekonomik gelişmişliğinin katkısı var. Ekonominiz üretim ekonomisine dönüşmedikçe, istihdam alanları açılmadıkça, ülkede yoksul insan olmaya devam edecek, bizde sosyal yardım vermeye devam edeceğiz. Önemli olan bu sosyal yardım vermeyi azaltmaya dönük politikalar geliştirmek. Sosyal politika deyince sosyal yardım öne çılkyor gibi gözüküyor. Toplumsal algı böyle. Sosyal politika nedir, fakire fukaraya aş, para, kömür, makarna vermek gibi algılanıyor. Algı o şekilde. Sanki realitede biraz öyle gibi" (12)

"Bu dönem dönem Türkiye'de değişiyor. Yeşil kart uygulamasıydı eskiden. Şimdi kömür yardımına, gıda kolisine dönüştü. Aklıma ilk gelen açısından. Ama olması gereken bu değil" (17)

Yoksullukla mücadele alanında bütünsel bakış açısının olması gerekliliğine işaret eden katılımcı, Türkiye'deki yoksullukla mücadele politikalarının sosyal yardım boyutu ile yürütüldüğüne ilişkin değerlendirmesini şu şekilde ifade etmiştir:

"Kuramsal olarak yoksullukla ilgili tabi ki koruyucu, önleyici ve güçlendirici bir yaklaşımla hizmetlerin, uygulamaların, önlemlerin planlandı̆̆ bütünsel bir sistem. Yani yoksulluk konusundaki her türlü yaşam koşullarının birey, aile, grup olarak yaşam koşullarının iyileştirilmesi, onların çeşitti hizmetlere erişiminin sağlanmast, yoksunluklarının giderilmesi, firsatlar ve kaynaklar yaratılması ve önleyici, zarar görebilirliklerinin de önlenmesi için önleyici hizmetlerin bir bütünü sistemi diyebilirim. Kaynak aktarımında, sosyal transferler, sosyal yardım boyutunda giden bir yoksullukla mücadele politikamı var. Bu da tabi ki Türkiye'nin Osmanlıdan gelen gelenekler, kültürel yapımızla çok alakalı. Sosyal yardım boyutunda giden bir sosyal politikamız var" (10) 
Sosyal politika uygulamalarının uygulayıcısı olarak yerel birimde uzun yıllar yönetici olarak görev yapan katılımcının görüşleri sosyal politikaların genel değerlendirmesi açısından dikkate değerdir:

"Yoksullukla ilgili sosyal politika dediğinizde ilk aklıma gelen koca bir üzüntü. İlk aklıma geleni söylüyorum gerçekten. Belki de bu işin içinde belki de bunu dışarıdan birine sorsanız, size devletin verdiği kömüründen bahseder. Ama 30 yıldır bu sahada çalışmış ve bu işin tüm aşamalarda nereye geldiğini görmüş biri için koca bir üzüntü derim." (5)

Yoksullukla mücadeleye yönelik sosyal politikaların, ağırlıklı olarak sosyal yardımlara dayanması ve sosyal güvenlik sistemini aşındırıcı etkilerinin bulunması olumsuz olarak değerlendirilmiştir. Bu yönüyle uzun dönem sosyal politikalarda, sosyal güvenliğin en önemli politika aracı olarak ekonomi politikalarıyla beraber yürütülmesi gerekliliğine dikkat çekilmiştir. $\mathrm{Bu}$ doğrultuda istihdamdaki kayıt dışılığa değinen katılımcılar, sosyal yardımların, sosyal güvenlik sistemini ve çalışma yaşamını olumsuz etkilemeyecek şekilde kurgulanması gerekliliğini vurgulamışlardır. Sosyal yardım alan kitlelerin, yardımlarının kesilmesi endişesiyle kayıtlı işler yerine kayıt dışı istihdama yöneldiğini belirterek, bazı durumlarda politika araçlarının birbirini kestiğini belirten katılımcı değerlendirmesini şu şekilde aktarmıştır:

"Sosyal güvenlik benim yaklaşımıma göre sosyal sigortaları, sosyal yardımı ve sosyal hizmeti içeren ana çatıdır. Sosyal yardım odaklı olarak sosyal politika inşa edildiği zaman sosyal güvenlik zayıflar. Bugün insanlar sigortalı çalışmak istemiyor, kayıt dışı çalışmak istiyor. Çünkü sosyal yardımdan olmak istemiyor. Çünkü sigortalı olduğunuz zaman sosyal yardım kesiliyor. Böyle olduğu zamanda aslında sosyal politik araçlar birbirini keser bir hale geliyor. O yüzden sosyal güvelik ama sosyal sigortalar, sosyal yardim ve sosyal hizmetlerin birbirini tamamlaylcı bir şekilde örtüştürülmüş bir sosyal güvenlik sistemi. Bizde şu an işsizliğin de etkisiyle sosyal güvenlik sisteminin işçi işveren boyutuyla taraflar azalırken, zayıflarken sosyal yardımlarda büyük bir genişleme var." (9)

Yoksullukla mücadele politikalarının sosyal yardımlara dayalı olarak yürütülmesi, araştırmaya katılan akademisyenler tarafından eleştirilmiştir. Sosyal yardımlar üzerinden yürütülen politikalara eleştirel açıdan yaklaşan akademisyene göre yoksulluğu ortadan kaldıracak politikalar yerine rahatlatıcı bazı uygulamalara yer verilmesi, yoksulluğu sürekli hale getirerek, bağımlılık yaratmaktadır:

"Yoksulluğu ortadan kaldiracak sosyal politika öncelikle yoksulluğa meydan vermeyecek sosyal politikadır. O anlamda insanı sosyal hizmetlerle desteklemek, buna rağmen yeterli olmayıp da halen yoksulluğa düşerse o zaman yardıma başvurmak gerekir. Malum tıpçıların söylediği önleyici hizmetler, tedavi edici hizmetler gibi sosyal politikada da aynı problem var. Yoksulluk ortaya çıktıktan sonra biz onu tedavi edelim anlayışı var. $O$ da hiçbir şekilde iyi tasarlanmamış, hak temelli olmayan ve de yoksulluğu birak ortadan kaldırmayı veya azaltmayl, yoksulluğu meşrulaştırıp, sürekli süründürerek yaşatmak ve çoğaltmak üzerine yapılmış bir yardım türü. İnsanları bağımlı kılıyor, insanlar artık yardım var diye başka iş yapmıyorlar. Ondan sonra da dönüp kurbanı suçlama, bak bunlar çalışmıyor, yardıma bağımlı oluyor. Yani böyle bir karmaşa var." (18)

Katılımcıların genel değerlendirmesi, yoksullukla mücadelede, mutlak yoksulların sosyal yardımlarla sürekli olarak desteklenmesinin gerekli olmasına karşın, yoksullukla mücadelede koruyucu, önleyici hizmetler uygulanmadığı sürece yoksulluğun ülke gündeminden kaldırılamayacağıdır.

Katılımcılar, yoksullukla mücadelenin ağırlıkla "koruyucu" nitelikli olup, yeterli düzeyde önleyici olmadığı görüşündedirler. Buna göre yoksulluğun tamamen giderilmesinin mümkün olamayacağı ve kimi zaman yoksulluk yönetilerek, buna uygun tedbirler alınmaktadır.

Türkiye yoksullukla mücadeleye yönelik politikalarda, Birleşmiş Milletler ve Avrupa Birliği gibi pek çok uluslararası sözleşmeye taraf olacak şekilde kısa, orta ve uzun dönemli çeşitli 
hedef ve stratejileri benimsemiştir. Genel anlamda uluslararası sözleşme esaslarına uyulmakla beraber bu sözleşmelerin iç hukuktaki bağlayıcılığ 1 , belirlenen hedef ve stratejilere uyumda önem kazanmaktadır. Araştırmada, bu sözleşmelerdeki hedef ve stratejilerinden ayrılarak, "paternalist devlet algısı" ile birlikte "klientalist ilişkilerin" ortaya çıktığı değerlendirmesi yapılmıştır.

Katılımcılar, yoksulluğun ortadan kaldırılması hedefinde, kısa dönemli sosyal desteklere dayalı politikalar yerine, yoksul hedef kitlenin "yapabilirlik sorununun çözümü” temel alınarak konuya bütüncül bir bakış açısıyla yaklaşılması gerekliliği üzerinde durmuşlardır. $\mathrm{Bu}$ değerlendirmelerin temelinde, orta ve uzun dönemde "bağıml bir yoksul kitle oluşumunu engelleyebilmek" için yapabilirliklerin arttırılmasının önemi yer almaktadır. Bu kapsamda daha fazla kitlenin yoksulluk zincirine girmemesi ya da bu zincirden çıkması için "yoksulun yapabilirliğinin ve becerilerinin geliştirildiği" sosyal politikaların temel alınması, eğitim, mesleki eğitim, sağlık, tarım ve göç gibi diğer politikalara gereken önemin verilmesinin yoksulluğun kısır döngüye dönüşmesini engelleyeceği görüşü hakimdir. Bu yönüyle Şenses'in (Şenses, 2014, s. 331) "yoksullukla mücadelede kalıcı bir başarı, gerek ulusal ve gerekse uluslararası düzlemde yoksulluk açığını kapamaya yönelik bir kerelik transferlerin çok ötesinde, büyüme sürecinden dışlanmış kesimlerin bu sürece katılmalarının sağlanabilmesine bağlıdır" değerlendirmesi önem kazanmaktadır.

\subsection{Yoksullukla Mücadele Politikalarının Amacı ve Hedefi}

2011 yılında 633 sayılı KHK ile kurulan Aile ve Sosyal Politikalar Bakanlığı, yoksullukla mücadele kapsamında "sosyal yardıma ve korunmaya muhtaç kesimlere arz odaklı yardım ve hizmetlerin sunulmasını" hedef olarak benimsemiştir (T.C. Aile ve Sosyal Politikalar Bakanlığı, 2013, s. 3).

Türkiye'de yoksullukla mücadeleye yönelik sosyal politikalara ilişkin Kanunlarda, Kalkınma Planlarında, Yıllık Programlarda, Hükümet Programlarında yoksullukla mücadelede sürdürülebilir büyümenin sağlanması, gelir dağılımının düzeltilmesi, eğitim, sağlık ve çalışma yaşamıyla ilgili politikaların beraber yürütülmesi, yoksulluk ve sosyal dışlanma riski bulunan bireylerin ekonomik ve sosyal yaşama katılımı hedeflenmiştir.

Bu hedefler ekseninde 10. Kalkınma Planında "yoksulluk ve sosyal dışlanma riski altında bulunan kesimlerin firsatlara erişimlerinin kolaylaştırılması yoluyla ekonomik ve sosyal yaşama katılımlarının artırılması ve yaşam kalitelerinin yükseltilmesi, gelir dağılımının iyileştirilmesi ve yoksulluğun azaltılması" temel amaç olarak benimsenmiş̧ir. Bu amacın gerçekleştirilmesinde "vatandaşları üretim sürecine daha fazla dahil edecek şekilde iyileştirilmesi gereği" vurgulanmıştır.

61. Hükümet Programında "aile bütünlüğü içinde" yaşlı, engelli, öğrenci, dul, yetim ve yoksullara destek sağlanarak, 2023 yılında mutlak yoksulluğun ortadan kaldırılması temel hedef olarak belirlenmiştir. 64. Hükümet Programında yoksullukla mücadelede "ihtiyacı olan herkese sosyal destek sunulmasını ve sosyal desteklere duyulan ihtiyacın azaltılması" temel hedef olarak benimsenmiştir. Bu doğrultuda, sosyal yardımlarda "ailenin bütünlügünü koruyan" ve "sosyal destek ve hizmetlerin hak temelli olarak bütünleşik sosyal destek sisteminin" oluşturulması temel alınmıştır.

Araştırmada katılımcılar, yoksullukla mücadeleye yönelik sosyal politikaların amacına ve hedefine yönelik değerlendirmelerini kısa, orta ve uzun dönemli olarak açıklamışlardır.

Yoksullukla mücadele kapsamındaki sosyal politikaların genel amacına ilişkin görüşler ağırlıklı olarak konuya bütüncül açıdan bakılması ve uzun dönemde yoksul hane sayısının ve yoksul faydalanıcı sayısının azaltmasına yönelik sosyal ve ekonomik tedbirlerin alınması gerekliliğidir. Yoksullukla mücadele politikalarının bütünsel olarak ele alınması gerekliliğine vurgu yapan katılımcının değerlendirmesi şu şekildedir: 
"Ĕ̈itime, sağlı̆̆a, bütün kamu hizmetlerine, insana yakışır yaraşır bir düzeyde hayat standardı sağlayarak bütün kamu hizmetlerine erişimi kolaylaştırmaktır, eşitliği sağlamaktır. Bu mutlak eşitlik değil elbette, asgari düzeyde belli bir hizmeti almasını sağlamaktır vatandaşın. Sosyal politikanın en temel amacı insanları belli bir hayat seviyesine ulaştırmaktır. Sosyal dişlanmaya maruz kalan bireylerin, grupların bu dışlanmadan kurtulmalarını sağlamaktır, toplumda var olmalarını sağlamaktır. Sosyal politikanın en temel amacı bütünsel bir şekilde insanın bütün kamu hizmetlerinden eşit bir şekilde yararlanmasını sağlamaktır. (2)

Türkiye'de yoksullukla mücadele politikalarının ana hedefinin "kişinin kendi ayakları üzerinde durabilmesi, istihdama katılımının sağlanması" olduğu şeklinde görüş belirten katılımcılar, istihdama katılımın yalnızca parasal anlamda değil, sosyal anlamda da güçlendirici etkisine değinerek, bunun yoksul bireyin çalışma alanındaki yapabilirliğiyle doğrudan alakalı olduğunu ifade etmişlerdir. Buradaki sorunun temelinde yoksul kişiler açısından ciddi bir yapabilirlik sorunu olduğunu ifade eden katılımcılar, mutlak yoksullar hariç tutulmak kaydiyla diğer yoksul kitle için yapabilirlik sorunuyla mücadelenin uzun dönemde yoksullukla mücadeleye yönelik politikalarda temel alınması gerekliliğini vurgulamışlardır. Bu yönüyle yapabilirliklerinin arttırılmadığı politikalarla yoksulluğun önlenemeyeceği gibi bağımlı bir yoksul kitle oluşturacağı endişesi hakimdir. Bu görüşle bağlantılı olarak, yoksul kişilerin sosyal yardımlara uzun süre bağımlı kılınmasını önlemek için yardımların miktarının bilerek düşük düzeyde tutulduğu ifade edilmiştir.

Katılımcılar, yoksullukla mücadelede sağlık, eğitim, istihdam, sosyal güvenlik ve ekonomik politikaların birlikte ele alınması gerektiği ve yoksulluğun sosyal yardımlarla sonlandırılamayacağı görüşündedirler. Buna göre sosyal politikaların diğer politikalarla desteklenmemesi durumunda "yoksulluk kültürü" oluşacaktır. Yoksullukla mücadele politikalarının bütüncül bakış ile diğer politikalarla desteklenmemesi durumunda yoksulluğun kanıksanacağını dile getiren katılımcıların görüşleri şu şekildedir:

"Insanların beşeri sermayelerinin gelişmesi demek eğitim ve sağlık alanında yapılan yatırımlarla onların beşeri sermayelerini de artması demektir ki toplumdaki kitlelerin beşeri sermayelerinin artması da o kişilerin topluma olan katkılarını artması ve toplumun genel refah düzeyinin de yükselmesi demek. Yani bu yönüyle de yoksullara yaptığınız yardımlar tek yönlü bir sadaka gibi değil, aslında orta ve uzun vadede toplumun kendisine de olumlu getirisi olan birer politikadır. Biz genel müdürlük olarak yoksulluk resminin sadece belli bir karesindeyiz aslında. En acil yardım kısmındayız. Bu en acil yardımı yaptzktan sonra bu kitlelerin diğer yönleriyle kendine yeter hale gelmesi için diğer politikalar yürütülmezse bizim alanımız ne kadar ideal ne kadar güzel olursa olsun zaten yetersiz kalır ve yoksulluk bir kisır döngüye dönüşür, yoksulluk kültürüne dönüşür ve bir süreklilik haline gelir, nesilden nesile aktarlan bir hale gelir. Ama bu bizim alanin iyi veya kötü yürütmemiz ile ilgili değil diğer alanların bizi desteklemesiyle ilgili. Diğer alanlarda güzel politikalar uygulanmazsa yoksulluk bir kisır döngüye dönüşür, dönüşmesi kaçınılmazdır" (8)

"Kamu kaynaklarının kullanımına baktığınızda, yoksulluk zincirinin kırılmasında önemli olan diğer alanlarında öneminin dikkate alınması. Ĕ̆itimdeki başarı oranı, sağlıktaki hizmetlere ulaşabilme, yaşlılikta bakım hizmetlerine ulaşabilme, engellilikte istihdam ile ilgili bu hizmet ve ihtiyaçların hepsi yoksullukta da çok alakall. Suçluluk konusuna bile baktığımızda kişi işsiz kalıyor, istihdam olamıyor, yeterli bilgi, beceri, eğitimi alamıyor, sağlık hizmetinden yararlanamıyor, suça yöneliyor, o tekrar bir döngüye giriliyor yoksul olduğu için, yoksulluk bu döngüyü çeviriyor. Asıl kilit noktalar kişinin kendi kendinin yeterli olabilmesini sağlayacak uzun vadeli birtakım programlar olmadığı sürece klsa vadeli, çoğunlukla da bizim sosyal yardım sistemimize baktı̆̆ımızda, yoksullukla mücadele stratejimize baktığımızda hala Sosyal Yardımlaşma ve Dayanışma Teşvik Fonunun temel bir yasasını, kanununu görüyoruz. Temel gereksinimlerini karşılamaya 
yönelik, kendi kendine yeterli olabilmeye yönelik bir amaç maalesef şu anda çok yok" (10)

Katılımcılar var olan yapıda, yoksul kitledeki “umut eksikliğine” ve sosyal yardımların yoksul hanelerde "yoksulluk kültürü̈" oluşturduğuna dikkat çekmişlerdir. Katılımcılar, yoksul kitlelere sağlanan sosyal yardımlara karşın, yoksul kitlede, bulundukları sosyo ekonomik düzeyin üzerine çıkma arzusunun yaratılamadığı görüşünü dile getirmişlerdir. Karşılaştırma yapılan yıllara göre yoksul kesime daha fazla sosyal yardım sağlanmasına karşın, hanelerin sosyo ekonomik düzeyinin geliştirilemediği, sosyal yardım uygulamalarının bu konuda etkin olmadığı, "yoksulluğu koruyan bir yapının” oluştuğu belirtilmiştir. Bu görüşlerle bağlantıli olarak yoksulluğun nesiller arası aktarımının engellenmesinde sadece sosyal yardımlar üzerinden değil, en önemli sosyal politika aracı olan eğitim konusunda fırsat eşitliğinin sağlanmasının önemine değinilmiştir

"Biz aslında yoksulluğu ortadan kaldırmıyoruz. Çünkü bizim vakıflar aracıllğıyla yapılan temel ihtiyaçlarını karşılamaya yönelik. Siz ayda kişiye 300 lira nakdi destek sağllyorsunuz. Bununla yoksulluğu ortadan kaldiramazsinız. Yoksullukla mücadele edersiniz, yoksulluğu daha az görünür kılarsınız. Benim görüşüm biz yoksullukla mücadele ediyoruz ama yoksulluğu ortadan kaldıramayı bu yaptıklarımızla. Eğitim kapsamında yapılan, hayata geçirilen sosyal politikalar, sosyal yardımların yoksul zengin ayrımı yapılmaksızın üniversal denilen kapsamda yapılması, bütün çocuklara yapılması gerekli. Mesela yoksullukla mücadele kapsamındaki en önemli silahınız eğitim olabilir. Daha iyi ę̆itim almalarını sağlamak. Yoksa o yoksulluk kültürünü oluşturuyorsunuz, yoksulluk kısır bir döngüye dönüşüyor, anne cahil baba cahil çocuk da cahil. Ondan doğacaklarda o döngüye dahil oluyor, kanıksıor." (14)

Katılımcıların tamamı, istihdama katılımı mümkün olmayan mutlak yoksullar açısından hak temelli ve sürekli sosyal yardımların gerekliliği ve bu kesimin sosyal hizmetlerle her alanda desteklenmelerinin sosyal politikaların gereği olduğu konusunda hem fikirdirler.

Sosyal politikaların, üretken ve donanımlı insan yetiştirilmesi için diğer politikalarla beraber yürütülmesi gerekliliğine vurgu yapılarak, politika uygulamalarında koşulluluk ilkesinin önemine dikkat çekilmiştir. Bu görüşlerin temel olduğu değerlendirmeler şu şekildedir:

"Temel hedef, bir, kendi kendine yeterli hale getirmektir, yoksulu yoksul olarak tutmak değildir. İki, bu politikaların temel hedefi sinıflar arasındaki farkları uca savurmak değil, sinifların arasindaki dengeyi birbirlerine yaklaştırmaktır. En alt seviyedeki düzeyi de asgari yaşam düzeyinin üzerine çıkartabilmektir. Ve bunun sunuş biçiminde de bir yurttaşlık geliri garantisi gibi bir şeyi oluşturmak gerek. Bütün bunlar sadece vermek üzerine kurulu politikalarla olmaz. Mutlaka üretimde, eğitimde, sağllkll, donanımlı insan yetiştirmekle örtüşmelidir. Bu okul öncesi eğitimden başlar, örgün ve yaygın eğitime kadar uzanir, istihdama kadar uzanır. Planlamayla olur bütün bunlar." (11)

"Yoksullukla ilgili sosyal politikaların tamamında bir amaç var. Ama maalesef bu amaçlar bizi istediğimiz hedeflere götürmüyor. Dolaylslyla bence ülkede oturup, yoksullukla ilgili sosyal politikaların yeniden revize edilerek, belki de tek hale getirilmesi, uygulanan tüm sosyal yardım politikalarinın tek bir kanun maddesinde toplanması gerek." Şartlı hale getirmezseniz asla bu ülkede yoksulluğu ortadan kaldıramazsınız" (5)

Araştırmada yoksullukla mücadele politikalarının sosyal risklerin önceden tespit edildiği bir anlayışla ve "arz bazlı" yaklaşımla belirlenmesinin gerekliliği vurgulanmıştır. Katılımcılar politika uygulamalarında koşulluluk ilkesinin temel alınmasının, özellikle şartlı nakit transferleri ile eğitimde kız çocuklarının okullaşmasında, sağlıkta, bebek ve anne ölüm oranlarının azalmasında etkili olduğu ve politikaların etkinliğinin arttığı görüşüne sahiptirler. 
Yoksullukla mücadeleye yönelik politikaların uzun dönemde yoksulluğu gideren değil, kısa dönemli, rahatlatıcı ve "günü kurtarıcı" nitelikte ve çözüm odaklı olmadığını ifade eden katılımcıların değerlendirmesi şu şekildedir:

"Yani yoksulluğu aşmak ve yoksullukta bir perde yukarı çıkmak üzerine değil. Aç kalmasın, yakıtı olsun, ama çözüm odaklı değil. Yani bağımlı tutuyor hala sizi, sisteme bağlı kallyorsunuz. Uzun vadeli çözüm değil. Kısa vadede rahatlatıcı çözüm" (3)

"Yoksulluğu yapısal düzeyde çözecek ve ortadan kaldıracak, insanları kendi ayakları üzerinde durabilir, kendi gelirlerini kazanabilir, harcayabilir duruma getirecek yapisal bir hedef yok. Daha çok günü kurtarmaya dönük, mevcut şikayetlenmeleri, sızlanmaları köreltecek ve ortadan kaldıracak nitelikte şeyler yapiliyor, bununla yetiniliyor" (21)

Katılımcılar yoksullukla mücadele politikalarının amaç ve hedefine yönelik değerlendirmelerinde aşağıdaki başlıkları dile getirmişlerdir.

- Yoksullukla mücadelede mutlak yoksullar hariç olmak üzere "yoksul kesimin yapabilirliklerini artıracak" şekilde kısa dönemli çözümlerle beraber orta ve uzun dönemli politikalarda bütüncül yaklaşımın temel alınması,

- $\quad$ Sosyal risklerin önceden tespit edildiği "arz bazlı" yaklaşım esaslı politika temellerinin benimsenmesi,

- $\quad$ Sosyal yardımlarla beraber sosyal hizmet ve sosyal güvenliğin birlikte değerlendirildiği politikaların oluşturulması,

- $\quad$ "Hak temelli anlayışa" göre belirlenecek politikalarda bu anlayışın yerleşebilmesi için kamuoyunda yeterince yer verilerek yoksul kitlenin bilgilendirilmesi için gerekli tedbirlerin alınmas1,

- $\quad$ Hak temelli anlayışla "asgari gelir desteği”" uygulamasına geçilmesi,

- $\quad$ Yoksul kitledeki "umut eksikliğini” gideren ve "yoksulluk kültürününe” yol açmayan politikaların belirlenmesi,

- Mutlak yoksullar hariç tüm sosyal politikaların "şartlılık esasına dayandırılması"

- Kayıtdışı ekonomi ve kayıtdışı istihdam dikkate alınarak yoksullukla mücadele politikalarında "kayıt dışılığı önleyici ekonomik ve sosyal politikaların" birlikte değerlendirilmesi,

- $\quad$ Yoksullukla mücadele kapsamında 2019 yılı itibariyle 47 olan sosyal yardımların yoksul kitle tarafından takibinin sağlanabilmesi için mevzuat bütünlüğünün oluşturulması konularına dikkat çekmişlerdir.

\subsection{Yoksullukla Mücadele Politikalarında Temel Alınan Yaklaşımlar}

Katılımcıların büyük bir çoğunluğu yoksullukla mücadeleye yönelik sosyal politikaların gereksinim temelli olarak yürütüldüğ̈̈ görüşündedirler. Buna göre var olan politikalardaki yaklaşım, ağırlıklı gereksinim temelli olup, kimi zaman hayırseverlik yaklaşımı da etkili olmaktadır. Yoksullukla mücadelenin devlete siyasi bir sorumluluk yükleyerek, sosyal hak kapsamında "hak temelli sosyal politika" anlayışının temel alınması gerekliliğine vurgu yapılmıştır.

Katılımcıların bir kısmının süreç üzerinden yaptıkları değerlendirmeler, Türkiye'deki bazı uygulamaların hak temelli anlayışa dönüştüğü şeklindedir. Buna göre özellikle 2002 yılından bu yana yaklaşım açısından farklılaşma yaşanarak, bazı uygulamalarda hak temelli anlayışa dönüşüm oluşmuştur. Bütünleşik Sosyal Yardım Sisteminin (BSYS) kullanılmaya başlandığı 2012 yılından itibaren oluşturulan puanlama sistemi hak temelli yaklaşıma dönüşümde etkin olmuştur: 
"2002'den bu yana ciddi ilerleme kaydedildi. Kurum profesyonelleşmeye başlamış ve artık burada eski yaklaşımlar kenara itilerek daha profesyonel bir yaklaşım sergileniyor. Biz hak temelli olması gerektiğini savunuyoruz. Şu andaki yaklaşımlarla ilgili ihtiyaç temelli diyebiliriz engelli ve yaşlıları dışarıda tutarsak, onları hak temelli diyebiliriz. Hak temelli ve ihtiyaç temellinin bileşimi diyebiliriz şu haline." (7)

"Şu an maalesef ihtiyaç temelli. Yani evriliyor. Şimdi puanlama sistemi var. Şu an kritik bir noktadayız. 2 sene önce konuşuyor olsak direk ihtiyaç temelli derdim. Şu anda yapısal değiş̧imden dolayı değişiklik var. Ama hala ihtiyaç temelli." (10)

2012 y1lı sonrasında Aile, Çalışma ve Sosyal Hizmetler Bakanlığının uygulamaya başladığı BSYS ile tüm sosyal yardımların ve sosyal hizmetlerin tek çatıda birleştirilmesi, sosyal yardım kararlarının etkin bir şekilde alınabilmesi, sosyal yardımların sunumunda zaman ve maliyetlerin azaltılması, başvuru sürecinin kolaylaştırılması hedeflemiştir. Bu kapsamda sosyal yardımların sunumunda bütüncül bir yaklaşım izleyebilmek için kurumlar arası bilgilerin paylaşımının sağlanması ve kurumlar arası programların bütünleştirilmesi temel alınmıştır (Türkiye'nin Bütünleşik Sosyal Yardım Sistemi, 2017).

BSYS'nin kurulmas1 ve uygulanması sonrasinda sosyal politikalardaki temel yaklaşımdaki değişime vurgu yapan katılımcılar, ana yaklaşımın sosyal devlet olmanın temel gereği olarak hak temelli olduğu görüşündedirler:

"Türkiye'de sosyal yardımlar sosyal devletin gereği olarak kamu hizmeti şeklinde olup ana yaklaşımımız hak temellidir." (23)

"Bizim resmi söylemimizde sosyal yardımları hak olarak veriyoruz, kesinlikle ulufe, lütuf gibi bir anlayışımı yok. Anlayış olarak asgari gelir desteği meselesine zaten açık durumdayız. Ama tek sıkıntımız bütçe. Bütçe olduğu sürece, zaten bizim Anayasamızdaki temel ilkede budur, devlet sosyal barışın sağlanması için, sosyal güvenliğin sağlanması için bütün önlemleri alır, bütçe kisitlar doğrultusunda. Temel kavramlarımız bu. Bütçe kısıtı olmadığı sürece her şeyi yapmak üzere sosyal devlet anlayışıyla çalışıyoruz" (22)

BSYS ile belli düzeyde kurumsallaşmanın yaşandığını belirten katılımcı uygulamalarda, "bir elin verdiğini öbür elin fark etmemesi mantığı" ile hareket edildiğini ifade etmiştir:

"Bakanlık olarak yaptığımız şeyler tamamen hak temelli bir mantıkta. Kişilerin deşifre edilmemesi, devletin en azından bir elinin verdiğini öbür elinin fark etmemesi mantığ içerisinde bu işi yaplyoruz. Bütünleşik sistemden sonra özellikle bu iş kurumsallaştt. 10 milyon düzenli yardım alan bir kitle için merhamet duygularlyla yapabileceğiniz bir şey değil. Zaten objektif olmak zorundasıniz. Biz tipik sosyal demokrat refah devletinin yaptığı anlamındaki bir yapıda değiliz ama küçümsenecek bir Akdeniz tipi de değil." (22)

Katılımcılardan bazıları yoksullukla mücadeleye yönelik sosyal politikalarda "hak temelli yaklaşımın mevzuatta yer almasına karşın uygulamalarda yeterince hak temellilik anlayışının olmamasını" eleştirmişlerdir. Bu eleştirinin temelindeki dayanak, politikaların talep esaslı olması ve talep esaslı politikaların varlığının hak temelli anlayışa tamamen ters olduğudur. $\mathrm{Bu}$ doğrultuda, yoksul bireylerin özneleşememesi nedeniyle demokratik standartta sosyal politika oluşturulamadığı, bunun sonucunda bireylerde, "bu benim için hak" anlayışı yerine, "yardıma muhtacım" anlayışı oluşmaktadır.

Uygulanan politikalar ile mevzuat arasındaki farklılığa dikkat çeken katılımcıya göre yoksullukla mücadele alanında hak temelli yaklaşım mevzuatla sınırlı olup uygulamada ihtiyaç temellilik ve hayırseverlik ön plana çıkmaktadır:

"Mevzuat üzerinde hak temelli, biraz daha devletin görevi olarak tanımlayan bir mevzuatımız var. Ama uygulamaya geldiğimiz zaman bu böyle değil. Tamamen yardım şu anda. Vakı mantığıyla gidiyoruz. Ihtiyaç temelli. Hak temelli anlayışımız metinlerde ifadelerimiz var. Ama zihnimiz henüz öyle değil" (16) 
"Metinlerde haylrseverlik yerine hak ve devletin yükümlülüğü șeklinde yazlyor, onlara lütuf edilen bir durum değil şeklinde, kesinlikle sosyal hak, sosyal devlet, insan hakk üzerinden tanımlanan bir şey. Onlara lütfedilen bir durum değil şeklinde biz bunu formülüze ediyoruz, yazlyoruz. Ama hem sunum esnasında hem de uygulama esnasinda maalesef bunlar bir hayırseverlik ve bir lütuf olarak sunuyoruz. Ben ne zaman bir araştırmanın zeminini oluştururken olayın mevzuatına baksam mevzuat çok güzel. Bunu uluslararası diğer benzer, muadil dokümanlarla karşılaşıtıdığımızda çok iyi yapılandırılmış mevzuatlarımız var. Bu isterseniz strateji belgesi olsun isterseniz eylem planı olsun isterseniz herhangi bir yönetmelik, kanun tasarısı olsun esas işin ben sahada uygulamada çöktüğünü görüyorum her seferinde. Mevzuat yönüyle sosyal dışlanmanın önlenmesi gözetiliyor. Ama uygulamaya geldiğiniz noktada gerek yaptı̆̆ımız araştırmalarda, diğer yaptığımız karşılaştırmalı rapor çalışmalarında ya da diğer analizlerde bunun baştaki hedefle yani mevzuatla çok örtüşmediğini görüyoruz." (16)

Bazı katılımcılar yoksullukla mücadeledeki yaklaşım konusunda tam bir tanımlama yapmanın güç olduğunu ifade ederek, farklı sosyal desteklerde farklı yaklaşımların uygulandığını belirtmişlerdir:

"Yaklaşım konusunda hepsinden biraz biraz geçerli. Hala hak değil, ama tamamen hayırseverlik de değil. Yardımların kriterinin net olmamasından dolayı hak açısından sıkıntı var. Yani uygulama birliğini hala tam olarak sağlayamadı̆̆ımız yardım türlerimiz var. Yoksa hayırseverlikte var bizde devletin yaptı̆̆ yardımlar da var, yükümlülük olarak gördügümüz düzenlemeler, yardımlarda var." (2)

Türkiye'deki yoksullukla mücadele politikalarının hak temelli olması gerekliliğine vurgu yapan katılımcılar, ekonomik kaynaklar nedeniyle bunun uygulanamadiğ durumlarda farklı kitleler için farklı hedeflemeler oluşturulduğunu belirtmişlerdir:

"Bizim ilkemiz hak üzerinde yürümesi gerektiği bu mantlk içerisinde gidiyoruz. Ama ne yapılıyor. Fiiliyatta bütçe ile ilgili bir sıkıntı ve kısıtı içerisindeyiz. Asgari gelir desteği gibi bizim için ideal olan şeyi her zaman yapmamı mümkün olmuyor. Bu durumda ne yapıyoruz? Farkl hedeflemeler yapmak durumunda kallyoruz. En kırllgan kim vardir gibi, onun üzerine gidiyoruz. Eşi vefat etmiş kadına yönelik yardım çıkıyor, asker ailesi, asker çocuk ailesi gibi bir yardım çıkıyor, kronik hastalıklarla ilgili başka bir yardım çıkıyor. Farklı ayrı ayrı müdahale alanları üzerinden sosyal yardım konusunu en azından yürütmek durumunda kallyoruz." (22)

"Daha çok ihtiyaç temelli gidiyor benim gördüğüm. Çünkü hak temelli yaklaşıma ülkenin ekonomisinin tamamen yeterli olduğunu düşünmüyorum. İhtiyaç temelli, başvuru ağırlıklı yani talep odakl bir hizmet şu anda sürdürülebiliyor. Bence de olması gereken bu. Arz odakl bir hizmete henüz daha tam olarak hazırlıklı değiliz." (13)

Katılımcıların büyük çoğunluğu, engelliler ve yaşlılar için 1976 yılından bu yana devam eden politika uygulamalarının hak temelliliğe yakın bir yaklaşımla yürütüldüğ̈̈ görüşündedirler.

Engelli maaşı ve 65 yaş maaşı olarak tanımlanan ve süreklilik kazanmış olan sosyal yardım ödemelerinin hak temelli olarak sunulmaya başlanmasına karşın diğer sosyal yardımların, bütçe kısıtları nedeniyle "hak" olarak benimsenmesi yerine "yardım" olarak sunulması tercih edilmektedir:

"Bazı yardımlarda düzenli maaşa geçenler var. Aslında onlar biraz hakka dönüşüyor. Engelli maaşı gibi, 65 yaş maaşı gibi, yaşlılık maaşı gibi. Ama bazı yardımlarımız hala hakka dönüşmemiş durumda. Sosyal devletin bir takım sosyal politika ile ilgili yükümlülükleri var. Ama bunlar devletin bütçesiyle orantılı bir şekilde karşılanır. Sosyal hakka dönüştüğü durumda şu anki bütçeye olan yükünden çok daha fazlası bir yük ortaya çıkma ihtimalinden dolayı bütçeyle uyumlu olsun diye o hak olmaktan ziyade yardım olarak sunulmaya devam ediyor. Yani şu anki politika yaklaşımı daha doğrusu vakıfların 
kurulduğundan beri, sosyal yardımlaşma fonunun kuruluşundan beri gelen yaklaşım daha çok bunun bir yardım olarak devam etmesi, ama kismen bütçe oranında düzenli maaşlar, aylıklarla aşama aşama yardımdan hakka dönüşme süreci başladı, ama çok da hızlı ilerlemiyor açıkçası." (8)

Sosyal yardımlarda temel alınan muhtaçlık ölçütlerinin, yasadan yasaya ve uygulamadan uygulamaya değişmesinin hak temellilik konusunda sorun olduğunu ifade eden katılımc1 görüşünü şu şekilde aktarmıştır.

"2022 sayıl yasadan yararlanan engellileri düşünün, kriter ne, muhtaçlık. Oradaki muhtaçlığın tanımı asgari ücretin 1/3'ü. Engelliler kanununa göre evde bakım hizmetindeki kriter ne yine muhtaçlı. Oradaki tanım asgari ücretin 2/3'ü. Bir muhtaçlı̆̆ın tanımında bile bir sürü farklllıklar var. Mesela askerlere yönelik, asker ve asker ailelerine yönelik yardımlarda muhtaçlık tanımı brüt asgari ücret. Ne kadar farklılar." (21)

Engelliler ve yaşlılar açısından 1976 yılındaki mevzuat doğrultusunda hak temelliliğe yakın bir sosyal politika yaklaşımı izlendiği görüşüne karşın yoksullukla mücadele politikalarının tamamına dikkate alındığında, Sosyal Yardımlaşma ve Dayanışma Vakıfları (SYDV) aracılığıyla yürütülen politikaların idari kararlarla yürütülmesi nedeniyle hak temellilikten uzaklaşıldiğl ve siyasi otoritenin tasarrufuna açık hale geldiği görüşü belirtmiştir:

"Hak temellilik konusunda ülkemizde sorunlar olduğunu düşünüyorum. Sosyal yardımların bir hak olduğuna inaniyoruz, ama bunun mevzuat alt yapist tam olarak bize bunu söylemiyor. Bu engelli ve yaşlılar açısından sorun değil. 1976'dan beri uygulanan bir kanun ve oturmuş bir uygulama var. Artık bu 65 yaşını doldurmuş, şu şartları sağlayan kişinin hakkıdır deniyor ve yasama organınca bu kanunlaştırıllyor, çıkarılıyor. Artık buna bir hak temelli demek mümkün. Ama Sosyal Yardımlaşma ve Dayanışmayı Teşvik Fonu kaynaklarıyla yapılan yardımlarda hak temelli olduğunu söylemekte güçlük çekiyoruz. Çünkü biraz daha idari kararlarla yürüyor ya da siyasi otoritenin de arkasında durması, desteklemesiyle yürüyor. Onun için hak temelliye doğru geçişin olması gerektiğini düşünüyoruz. O açıdan hak olarak görme noktasında eksiklerimiz olduğunu düşünüyorum ülkemizde." (7)

Yoksullukla mücadele politikalarının hak temelli olmadığını belirten akademisyen sistemin çok parçalı olarak işletildiğini, vakıf uygulamalarına değinerek açıklamıştır. Politika uygulamaları geçici nitelikte olup, gereksinim temellinde yürütülmektedir. Hak temelli politikalar açısından en önemli ölçütün hakkın aranması noktasında yaşanan sorunlara göre değerlendiren katılımc1 görüşünü şu şekilde aktarmıştır.

"Bizdeki sistem asgari gelir güvencesi sağlayan bir sistem değil. Palyatif, çeşitli, biraz tarihsel, o, o zaman konmuş bu, bu zaman konmuş, sonra bir de bu eklenmis, işte onu değiştirmeyelim yerine bir de bunu koyalım gibi çok parçalı bir sistem zaman içerisinde geliş̧tirilmiş ve hak temelli değil. Bir şeyin hak temelli olmass ne demek, hukuki korumasının olması demek. Bizde ki sistemin en önemli bileşeni nedir, Sosyal Yardımlaşma ve Dayanışma Vakıfları. Bizde ki Yardımlaşma ve Dayanışma Vakıfları tüm il ve ilçelerde örgütlü. Tüm il ve ilçelerde örgütlü olan bu yapının hukuki statüsü ne? Özel hukuk tüzel kişiliği, yani vakıf. Özel hukuk tüzel kişiliğine sahip olan bu vakıfların finansmanı kim tarafindan yapıllyor? Kamu tarafindan yapıllyor. Türkiye'de özel hukuk tüzel kişiliğine yani vakıf statüsünde olan tek kurumlar mi? Yani siz gerçekte bir kamu kurumu olmayan yapıya kaтu fonu aktarlyorsunuz, benzerlerinden ayırt ederek, ayrımcilık yapıyorsunuz. Müdür İ̧ Kanununa göre çallşıyor ve orada çalışan sosyal yardım ve inceleme görevlileri İ̧̧ Kanunlarına göre çalışlyor yani kamu görevlisi değiller. Ama kamu görevi yerine getiriyorlar. Ve ben diyelim ki oradaki hizmetlerden yararlanmak isteyen birisiyim ve benim hakkımda yapılan değerlendirmenin isabetsiz olduğunu düşünüyorum, hukuksuz olduğunu düşünüyorum. Ne yapacağım? Bu bir kamu hizmeti olsaydı idare mahkemesine dava edecektim. Kamu hizmeti verenler, işlem yapanların kamu görevlisi olduğunu 
düşünürsem. Ama değiller, ancak hizmetin kendisi kamu hizmeti. Nereye dava edeceğim o kişinin yaptı̆̆ de ğerlendirmeyi. İdari açıdan müdüre şikayet ettim ya da mütevelli heyete gittim. Ama yargısal korumayı nereden sağlayacă̆ım, o bile belli değil. Dolayısıla hem idari kanallarla hem yargısal kanallarla hak arama yollarını açık açık tayin etmediği ve anlatmadı̆̆ için bu ayrımcılı̆̆a da son derece açık bir uygulama. Ben hak ettiğim halde bana ulaşmayabilir hizmet. Siz hak etmediğiniz halde size ulaşabilir. Tamamen öznel bir değerlendirmeye dayalı olabilir. Falanca ilde vakıf şu türden bir yardim ya da hizmet programlamış olabilir. Ama benzer bir hizmeti, yardımı benzer bir vakıf benzer bir il ya da ilçede programlamayabilir. Bu kadar keyfidir. Dolayısıyla ayrımcılıkla ilgili sağlam güvenceleri olan bir sistem değil." (21)

Yoksullukla mücadelede, sosyal devlet anlayışı doğrultusunda, mutlak yoksullar için hak temelli yaklaşımların gerekliliği belirtilerek göreli yoksullar için istihdama katılımın sağlanacă̆ tedbirlerin gerekliliğine dikkat çekilmiştir:

"Mutlak yoksulları ayırmalısını. Mutlak yoksullara lütuf olmaktan çıkartıp, sosyal devletin görevi olarak hak olarak vermelisiniz. Göreceli yoksullar için bir şekilde istihdama katılımların ya da sosyal hizmet müdahaleleriyle belirli bir süre sonra kendi kendilerini idare edebilir hale getirmelerini sağlamak durumundasınız." (5)

Yoksullukla mücadele politikalarının sosyal bir hak olarak yürütülmesinde, birbirini kesen politikalar olduğunu belirten akademisyen katılımcının görüşü, yasal mevzuatta hak temelli olan politikaların, uygulama sürecinde çeşitli nedenlerle hak temelli olmaktan uzaklaştığ 1 şeklindedir:

"Yasalar yapılıyor. Yasa yapmışsınız fakat bir de yasanın işleyişi, uygulaması var. Oradaki durumda çok ilginç şeyler oluyor. Mesela bu bizim kültürümüze uymaz, bizi aşar deyip işleyiş ve uygulama yönetmeliğinde icabında ters düşebilecek yasanın ilkeleriyle ters düşebilecek uygulamalara geçildi. Mesela bu anlamda bir taraftan bir eliyle kadın istihdamını arttırmak istiyor, tabi ki bu önemli. Ama öbür eliyle de yaşll, engelli, çocuk bakımını kadına yüklüyor. Hak temelli sosyal politika sloganımız var. Tamam da hak temelli ile bu aile temelli sosyal politika birbiriyle çelişiyor çünkü. Hak deyince bireyi anliyoruz, bireylerin hakları. Tasarımların iyi yapılması lazım. Tasarımın tabi ki hak temelli o bireyin haklarını koruyacak, bireyi kimseye muhtaç etmeyecek şekilde yapmalı. Bağımlılık yaratmayacak, hak temelli, bağımsız bireyin ayakta durmasını sağlayacak bir yardım politikamız yok." (18)

Siyasi parti temsilcilerinde yoksullukla mücadeleye yönelik sosyal politikalara gereksinim ve hayırseverlik yaklaşımıyla bakıldı̆̆ ve bu politikalara bir manipülasyon alanı olarak yaklaşıldĭ̆ı düşüncesi hakimdir. Yoksullukla mücadele politikalarının etkinliğinin sağlanmasında bu konunun siyaset üstü olarak değerlendirilmesi gerektiğini dile getiren siyasi parti temsilcisi görüşünü şu şekilde aktarmıştır.

"Bütün politik partilerin, siyasi iktidarların, devletin herhangi bir keyfi pozisyonundan çıkarılıp, objektif kriterlerde uygulanması gereken bir hak olarak olur" (20)

Katılımcıların ağılıklı olarak yoksullukla mücadeleye yönelik sosyal politikaların temelinde yer alan yaklaşımlara ilişkin görüşleri aşağıdaki başlıklar altında yer almıştır.

- $\quad$ Yoksullukla mücadeleye yönelik sosyal politikalarda gereksinim temelli yaklaşımın temel alındiğ

- $\quad 2012$ y1lından itibaren uygulanmaya başlayan BSYS ile hak temelli anlayışa doğru bir dönüşüm yaşanmaya başladığı,

Sosyal politikalara ilişkin plan ve programlarda hak temelliliğe vurgu yapılarak, bu alanda zihinsel bir dönüşümün oluştuğu, 
- $\quad$ Yoksul engelli ve yoksul yaşl hedef kitleleri için yürütülmekte olan sosyal politikaların hak temelli anlayışa en yakın sosyal politikalar olduğu,

- $\quad$ Yoksullukla mücadele politikalarının siyasi manipülasyonlara açık bir anlayışla gereksinim ve hayırseverlik yaklaşımıyla yürütüldüğü,

- $\quad$ Mevzuatta hak temelliliğe vurgu yapılmasına karşın uygulamaların bu yönde olmadı̆̆ı,

- $\quad$ SYDTV aracıllı̆ı̀la yürütülen politikalarla hak temelli uygulamaların söz konusu olamayacağı,

- Vakıflar aracılı̆̆ıyla yürütülen uygulama farklılıklarının hak temellilikten uzaklaşılmasına neden olduğu,

- $\quad$ Türkiye'nin var olan ekonomik yapısında sosyal politikaların hak temelli olarak yürütülmesinin var olan kaynaklar açısından mümkün olamayacağı,

- $\quad$ Hak temelli uygulamaların ekonomik nedenlerle uygulanamaması nedeniyle yeni eklenen hedefleme mekanizmalarıyla yeni hedef kitleler oluşturularak geçici çözümlerle soruna müdahale edilmeye çalışıldığı,

- $\quad$ Hak temelliliğin temel ölçütü olan hak sahibinin hukuki açıdan hakkını arama noktasında SYDV aracılığıyla yürütülen politikaların uygulama aşamalarında hukuki ve idari anlamda sorunlar yaşandığı belirtilmiştir.

\section{Sonuç ve Öneriler}

Araştırma kapsamında katılımcıların yoksullukla mücadeleye yönelik sosyal politikalara yüklediği en önemli kavram sosyal yardımlardır. Katılımcıların büyük kısmı yoksullukla mücadele politikaları konusunda kaliteli eğitim, kaliteli sağlık haklarına ulaşmanın önemine değinerek, yoksulluğun nesiller arası aktarımının önlenmesi noktasında gelir dağılımını düzeltici politikalar ve piyasaların kayıt altına alınması gerekliliğini vurgulamışlardır. Var olan kayıt dışılık nedeniyle uygulanan sosyal politikaların etkinliğinin azaldığı ve hedef kitle içinde sosyal adaletsizliklerin oluştuğu görüşüne varılmıştır.

Yoksullukla mücadeleye ilişkin sosyal politikaların amacı ve hedefine yönelik değerlendirmelerde uzun dönemde benimsenmesi gereken yaklaşımlar açısından katılımcılar benzer konulara vurgu yapmışlardır. Katılımcıların değerlendirmeleri, soruna uzun dönemli yaklaşılması, politikaların yalnızca sosyal yardımlara dayandırılmaması, sosyal hizmetlere gereken önemin verilmesi, eğitim, sağlık gibi diğer alanlardaki politikalarla beraber yürütülmesi ve bütüncül bir bakış açısıyla yaklaşılması gerekliliğidir. Uzun dönemde olması gereken bu yapıya karşın uygulamaların kısa dönemli hedeflerle yürütülmesi nedeniyle yoksulluğun bu anlayışla ortadan kaldırılamayacağı görüşü hakim olmuştur. Bu görüşlerin özellikle sosyal politika belirlemede etkili uzmanlar ve yöneticiler tarafından ifade edilmiş olması, yoksullukla mücadeledeki politikaların değerlendirilmesi noktasında bu görüşleri daha da önemli kılmaktadır.

Araştırmada, yoksullukla mücadele kapsamındaki politikaların belirlenmesinde etkin olan uzmanların genel değerlendirmesi, Türkiye'deki yoksullukla mücadelenin gereksinim temelli olarak yürütüldüğ̈̈; henüz hak temelli olarak yürütülmediği şeklindedir.

2000 y1lından bu yana, dünyadaki değişimler ve yoksullukla mücadeleye yönelik Birleşmiş Milletlerin benimsediği ölçütler doğrultusunda, Türkiye'de de buna paralel olarak mutlak yoksullukla mücadelede mesafe alındığı görülmektedir. Dünya Bankası ölçütleri doğrultusunda Türkiye'deki gıda yoksulluğunun neredeyse sıfıra yaklaşmış olması, bu alanda önemli bir başarı sağlandığı sonucunu vermektedir. Bu verilere karşın Birleşmiş Milletlerin ve Avrupa Birliğinin yoksulluk ölçütleri temel alındığında Türkiye'deki yoksullukla mücadelede var olan yoksulluk verilerinin ayrıntılı olarak irdelenmesi önem kazanmaktadır. Bu kapsamda insani gelişmişlik endeksinde artı̧̧ sağlamaya yönelik tedbirler önem taşımakta olup, toplumsal cinsiyet ayrımcılığı, çocuk işçiliği, düşük eğitim düzeyi, bazı bölgelerde yüksek nüfus artışı, kırsal kesim 
yoksulluğu, çalışan yoksulluğu, gelir dağılımındaki adaletsizlik, kadın istihdam oranlarına ilişkin politika uygulamaları yoksullukla mücadelede dikkate alınması gereken kritik noktalardır.

\section{Kaynakça}

DPT. (2013). 2014-2018 Onuncu kalkınma planı. Ankara: T.C. Başbakanlık Devlet Planlama Teşkilatı.

Gül, H., \& Sallan Gül, S. (2008). Türkiye' de yoksulluk, yoksulluk yardımları ve istihdam. n. oktik içinde, Türkiye' de Yoksulluk Çalışmaları (ss. 361-396). İzmir: Yakın Kitabevi Yayınları.

Şenses, F. (2013). Neoliberal küreselleşme çağında yoksulluk araştırmalarındaki kayıp bağlantılar: Türkiye deneyiminden çıarılacak dersler . F. Şenses içinde, Neoliberal Küreselleşme ve Kalkınma (ss. 679-704). İstanbul: İletişim Yayınları.

Şenses, F. (2014). Küreselleşmenin öteki yüzü yoksulluk. İstanbul: İletişim Yayınları.

T.C. Aile ve Sosyal Politikalar Bakanlığı. (2013). 2013 yıl faaliyet raporu. Ankara: T.C. Aile ve Sosyal Hizmetler Bakanlığı.

Thorbecke, E. (2006). The evolution of the development doctrine, 1950-2005. UNU-WIDER anniversary conference, 'WIDER thinking ahead: The future of development economics (ss. 1-37). Research Paper No. 2006/155.

Türkiye Büyük Millet Meclisi. (tarih yok). Ağustos 26, 2017 tarihinde https://www.tbmm.gov.tr/kutuphane/e_kaynaklar_kutuphane_hukumetler.html adresinden alınd 1

Türkiye'nin Bütünleşik Sosyal Yardım Sistemi. (2017). Ankara: T.C. Aile ve Sosyal Politikalar Bakanlığı.

\footnotetext{
ETİK ve BİLIMSEL İLKELER SORUMLULUK BEYANI

$\mathrm{Bu}$ çalışmanın tüm hazırlanma süreçlerinde etik kurallara ve bilimsel atıf gösterme ilkelerine riayet edildiğini yazar(lar) beyan eder. Aksi bir durumun tespiti halinde Afyon Kocatepe Üniversitesi Sosyal Bilimler Dergisi'nin hiçbir sorumluluğu olmayıp, tüm sorumluluk makale yazarlarına aittir. Yazarlar etik kurul izni gerektiren çalışmalarda, izinle ilgili bilgileri (kurul adı, tarih ve sayı no) burada belirtmişlerdir.
}

Kurul adı: Hacettepe Üniversitesi Senatosu Etik Komisyonu

Tarih: 09 Ekim 2018

No: $35853172-300$ 